\title{
OS ATOS DE DISPOSIÇÃO PROCESSUAL - PRIMEIRAS REFLEXÕES / THE ACTS OF PROCEDURAL PROVISION - FIRST REFLECTIONS
}

\author{
Leonardo Greco*
}

\section{Resumo}

O presente artigo busca discutir os atos de disposição das partes na relação processual. Serão discutidos no artigo os limites do poder de disposição das partes, o momento de sua eficácia, o seu regime jurídico processual ou de direito material e a revogabilidade dos atos em que é exercido.

Palavras-chave: Atos de disposição processual. Limites. Eficácia. Regime jurídico processual. Revogabilidade.

\begin{abstract}
This article seeks to discuss the acts of disposal of the parties in the procedural relationship. Will be discussed in this article the limits of the right of disposal of the parties, the moment of its effectiveness, its procedural legal rules or substantive law and the revoking of the acts in which it is exercised.
\end{abstract}

Keywords: Acts of procedural provision. Limits. Effectiveness. Procedural legal regime. Revocability.

1. Considerações gerais. A concepção publicística do processo relegou a segundo plano a reflexão acadêmica sobre os limites da autonomia da vontade das partes a respeito da multiplicidade de questões que podem ser suscitadas no processo ou foi levada simplesmente a considerá-la sempre dependente da aprovação ou homologação do juiz, vigilante guardião dos fins sociais e do interesse público a serem atingidos e preponderantemente tutelados. 
Ninguém defendeu com mais veemência essa concepção entre nós do que BARBOSA MOREIRA, em mais de um estudo ${ }^{1}$, nos quais sempre criticou certas ondas privatizantes que, procurando associar o ativismo judicial a ideologias autoritárias, defenderam a adoção de um sistema processual em que preponderasse a autonomia da vontade das partes, como consequiência de uma visão liberal e garantística do processo.

Apesar disso, o reconhecimento do processo civil como instrumento de tutela efetiva das situações de vantagem que a ordem jurídica confere aos particulares, decorrência da eficácia concreta dos direitos dos cidadãos característica do Estado Democrático contemporâneo, tem levado boa parte da doutrina e os sistemas processuais, em maior ou menor escala, a reconhecer às próprias partes certo poder de disposição em relação ao próprio processo e a muitos dos seus atos, reservando em grande parte à intervenção judicial um caráter subsidiário e assistencial ${ }^{2}$. E quando me refiro a esse poder de disposição, o faço não somente no sentido da prática de atos prejudiciais aos seus autores, mas de verdadeiros atos decisórios que vão determinar a marcha do processo e nele produzir efeitos jurídicos, ou, conforme a lição de CARNELUTTI, de atos mediante os quais "o agente regula, segundo o seu interesse, a composição ou o desenvolvimento do processo" $"$.

Não obstante esse poder das partes se contraponha ao poderes do juiz, não deve ser interpretado, de forma alguma, como uma tendência de privatização da relação processual, mas representa simplesmente a aceitação de que aquelas, como destinatárias da prestação jurisdicional, têm também interesse em influir na atividade-meio e, em certas circunstâncias, estão mais habilitadas do que o próprio julgador a adotar decisões sobre os seus rumos e a ditar providências em harmonia com os objetivos publicísticos do processo, consistentes em assegurar a paz social e a própria manutenção da ordem pública.

\footnotetext{
* Professor Titular de Direito Processual Civil da Faculdade Nacional de Direito da Universidade Federal do Rio de Janeiro; Professor Adjunto da Universidade do Estado do Rio de Janeiro; Professor dos Programas de Pós-Graduação em Direito da Faculdade de Direito de Campos e da Universidade Gama Filho.

1 V. especialmente "O neoprivatismo no processo civil", in Temas de Direito Processual, 9ª série, ed.

Saraiva, São Paulo, 2007, p.87/102.

2 Um retrato da influência das ideologias no Direito Processual Civil pode ser encontrado na recente obra Proceso civil e ideologia, coordenada por Juan Montero Aroca (ed. Tirant lo Blanch, Valencia, 2006), com ensaios de Franco Cipriani, Giovanni Verde, Girolamo Monteleone, Joan Pico i Junoy, José Carlos Barbosa Moreira (o estudo citado na nota anterior), Adolfo Alvarado Velloso, Federico G. Dominguez, Eugenia Ariano Deho e Luís Correia de Mendonça, e duas cartas trocadas por Augusto Mario Morello e Juan Montero Aroca.

${ }^{1}$ Francisco Carnelutti, Sistema de derecho procesal civil, v. III, ed. Uteha Argentina, Buenos Aires, 1944, p.7.
} 
Afinal, se o processo judicial não é apenas coisa das partes, são elas as destinatárias da tutela jurisdicional e são os seus interesses que a decisão judicial diretamente atinge, e, através deles, os seus fins últimos, embora remotos e abstratos, de tutela do interesse geral da coletividade, do bem comum e da paz social.

Entre esses atos de disposição, encontram-se as convenções das partes, assim entendidos todos os atos bilaterais praticados no curso do processo ou para nele produzirem efeitos, que dispõem sobre questões do processo, subtraindo-as da apreciação judicial ou condicionando o conteúdo de decisões judiciais subseqüentes. O que caracteriza as convenções processuais ou é a sede do ato - ato integrante da relação processual, praticado no processo -, ou é a sua finalidade de produzir efeitos em determinado processo, presente ou futuro. Muitos atos convencionais produzem efeitos em processos atuais ou futuros, embora não predispostos para esse fim. É o caso, por exemplo, do contrato de locação na ação de despejo. As partes contrataram a locação para reger a relação jurídica entre elas e não para servir de critério para o julgamento da procedência ou improcedência da ação de despejo. Apesar de utilizado pelo locador para fundamentar a ação de despejo por infração contratual, o contrato de locação não é uma convenção processual.

O conteúdo dos atos de disposição processual pode compor-se de questões substantivas - relativas ao direito material das partes - ou de questões tipicamente processuais - relativas a pressupostos processuais, impulso processual, admissão ou não de provas etc. Pouco importa. Umas e outras são questões do processo, suscitadas na relação processual, nela apreciadas e destinadas a produzir efeitos, sem prejuízo de eventualmente também produzirem efeitos fora do processo.

BARBOSA MOREIRA, num dos poucos estudos sobre o assunto na literatura brasileira, ressalta a disciplina lacunosa que os atos convencionais têm merecido, assim como, louvado em doutrina alienígena, distingue claramente as convenções daquelas declarações de vontade unilaterais cuja eficácia fica na dependência da concordância da parte contrária, como a desistência da ação ${ }^{2}$.

CARNELUTTI, no Sistema, já diferenciava os acordos dos contratos ou convenções, aqueles como atos complexos, ou seja, atos bilaterais em que a declaração de vontade de

\footnotetext{
2 José Carlos Barbosa Moreira, “Convenções das partes sobre matéria processual”, in Temas de Direito Processual, $3^{a}$ série, ed. Saraiva, São Paulo, 1984, p. 88/89.
} 


\section{Quaestio Iuris}

cada parte preserva a sua autonomia em relação à da outra, enquanto estes últimos são atos compostos, nos quais nenhum dos elementos do ato constitui um ato jurídico singular ${ }^{3}$.

NICETO ALCALÁ-ZAMORA Y CASTILLO refere-se às "partes que penetram na área do julgador", não se detendo na sua estrita qualidade de sujeitos que pedem, mas se transformam em sujeitos que decidem, como ocorre na prorrogação da competência, na fixação em certos casos do procedimento a ser observado, na transformação de um juízo em outro por acordo entre os litigantes ou mediante declaração unilateral de apenas uma das partes ${ }^{6}$.

Uma investigação sobre o novo alcance que vêm assumindo os atos processuais das partes certamente exigirá uma revisão da doutrina dominante, segundo a qual não cabe perquirir o conteúdo da vontade ou da causa nesses atos, cujos efeitos são prédeterminados pela lei ${ }^{4}$.

De algum modo essa revisão já se iniciou, especialmente através da sistematização de CARNELUTTI, que defendeu a existência de verdadeiros negócios jurídicos processuais, especialmente em atos dispositivos das partes e a transcendência jurídica da vontade e da causa na teoria dos atos processuais ${ }^{5}$. Mais recentemente, SILVIA BARONA VILAR, na Espanha, propõs a distinção entre os atos das partes destinados a obter uma resolução judicial, como a proposição de uma prova, e os criadores de situações jurídicas, como a desistência, a renúncia, a transação, a indicação de endereço para receber intimações e o acordo entre as partes na designação do perito ${ }^{6}$.

Nestes primeiro estudo sobre os atos de disposição das partes serão, a princípio, ignoradas essas distinções, para nos concentrarmos especialmente no exame de quatro questões a respeito de um primeiro grupo de fenômenos processuais: os limites do poder de disposição das partes, o momento de sua eficácia, o seu regime jurídico processual ou de direito material e a revogabilidade dos atos em que é exercido. Em estudos

\footnotetext{
${ }^{3}$ Francisco Carnelutti, ob. cit., p. 117. 6 Niceto Alcalá-Zamora y Castillo, "El antagonismo juzgador-partes: situaciones intermedias y dudosas", in Estudios de teoria general e historia del proceso (1945-1972), tomo I, ed. UNAM, México, 1974, p.292/293.

${ }^{4}$ V. Giovanni Verde, Profili del processo civile, vol.1, Jovene ed., Napoli, $6{ }^{\mathrm{a}}$ ed., 2002, p.286.

${ }^{5}$ Ob.cit., p.87, 417/448 e

$451 / 485$.

${ }^{6}$ Juan Montero Aroca et. Alii, El nuevo proceso civil (Ley 1/2000), ed. Tirant lo Blanch, Valencia, 2000, p. $163 / 164$
} 


\section{Quaestio Iuris}

vol.04, n-01. ISSN 1516-0351

subseqüentes tentaremos dar continuidade à análise dessas questões num rol mais numeroso e mais complexo de atos de disposição e, quiçá, identificar outras afinidades que sirvam para uma compreensão mais adequada da distribuição entre o juiz e as partes dos poderes de direção do processo civil. Mas, antes, impõe-se recordar alguns princípios e regras vigentes no Direito brasileiro que poderão servir de critérios para a análise projetada.

A instauração do processo resulta em geral da iniciativa do autor (art. 262 do CPC), que individualiza a demanda através da chamada tríplice identidade, fixando o chamado objeto litigioso. Ao réu também incumbe definir as questões de direito material que possam ilidir o pedido do autor, ressalvadas as de ordem pública, que o próprio juiz pode suscitar (CPC, art. 303, inciso II). Os fatos geradores do direito material das partes, a que a lei se refere como fatos constitutivos, extintivos, modificativos ou impeditivos do direito do autor (CPC, arts. 326), também se sujeitam, em princípio, ao ônus da sua afirmação pelas partes.

Quanto às questões propriamente processuais, cumpre recordar que a falta de condições da ação e de pressupostos processuais, de um modo geral, é matéria apreciável de ofício, pouca margem havendo para a disponibilidade das partes, constituindo exceções a argüição da incompetência relativa e a argüição do compromisso arbitral (CPC, arts. 114 e $301, \S 4^{\circ}$ ). Ademais, ao juiz incumbem os deveres de impulsionar o processo (CPC, arts. 125 e 262) e de determinar de ofício a produção de todas as provas necessárias à formação do seu convencimento $\left(\right.$ art. 130) ${ }^{7}$, o que reserva à autonomia de vontade das partes pouco espaço para deliberações a respeito da marcha do procedimento e para a imposição de limitações probatórias ao juiz, apesar da expressa previsão legal de convenções sobre a distribuição do ônus da prova (art. 333, parágrafo único) e do chamado ônus subjetivo, que faz recair sobre a parte que não demonstrou os fatos que a ela interessam a conseqüência do julgamento desfavorável.

2. Limites. A definição dos limites entre os poderes do juiz e a autonomia das partes está diretamente vinculada a três fatores: a) à disponibilidade do próprio direito material

\footnotetext{
${ }^{7}$ Talvez o maior reflexo do dilema liberdade $\mathrm{x}$ autoridade no processo civil moderno se encontre na iniciativa probatória. Nos países que adotam códigos considerados liberais, essa iniciativa incumbe exclusivamente às partes, o que é tido como conseqüência necessária do princípio dispositivo (V. Salvatore Satta, Manual de Derecho Procesal Civil, vol.I, ed. EJEA, Buenos Aires, 1971, p.165/166), que se contrapõe ao princípio inquisitivo, prevalente nas causas que versam sobre direitos indisponíveis.
} 


\section{Quaestio Iuris}

vol.04, n-01. ISSN 1516-0351

posto em juízo; b) ao respeito ao equilíbrio entre as partes e à paridade de armas, para que uma delas, em razão de atos de disposição seus ou de seu adversário, não se beneficie de sua particular posição de vantagem em relação à outra quanto ao direito de acesso aos meios de ação e de defesa; e c) à preservação da observância dos princípios e garantias fundamentais do processo no Estado Democrático de Direito.

No processo judicial entre duas partes - e eu afasto, por ora, do meu exame as ações coletivas e os procedimentos concursuais -, os interesses de ambas podem ser disponíveis ou indisponíveis, ou apenas o de uma delas ser indisponível e o da outra ser disponível. Os titulares de direitos disponíveis podem dispor no processo do seu próprio direito material, assim como de todas as faculdades processuais cuja não utilização possa resultar, direta ou indiretamente, em julgamento contrário ao seu direito material. Como todo ato de disposição, deve ser livre e consciente: livre, por não ter sido resultado de qualquer coação ou intimidação por parte de outro sujeito que, em razão da sua posição de superioridade em relação ao disponente, impõe-lhe a sua vontade para sujeitá-lo a um mal qualquer, ainda que justo; e consciente de que o ato de disposição pode lhe acarretar o julgamento desfavorável ou a perda do próprio direito material pleiteado em juízo.

Isso não significa que os titulares de direitos indisponíveis não possam praticar atos de disposição, tanto no sentido de atos prejudiciais quanto de atos decisórios, mas apenas que não podem praticar os que, direta ou indiretamente, possam prejudicar ou dificultar a tutela desses direitos.

O equilíbrio contratual e a paridade de armas também limitam a liberdade de disposição das partes. Exemplo recente nesse sentido encontra-se na Lei 11.280/2006, que facultou ao juiz reconhecer de ofício a nulidade de cláusula de eleição de foro em contrato de adesão, dando nova redação ao parágrafo único do art. 112 e ao art. 114 do Código de Processo Civil. Como já acentuei em outro estudo, a igualdade das partes deve ser concreta, e não apenas formal, o que exige um juiz vigilante para suprir, em caráter assistencial, as deficiências defensivas do mais fraco em relação ao mais forte. A posição de dependência de uma parte em relação à outra, a inferioridade econômica em decorrência da pobreza ou da proeminência do Estado, são circunstâncias que criam uma 


\section{Quaestio Iuris}

desigualdade concreta a exigir permanente intervenção equalizadora do juiz e a limitar o seu poder de disposição ${ }^{8}$.

A preservação da observância dos princípios e garantias fundamentais do processo é o que me ocorre denominar de ordem pública processual ${ }^{9}$. Já me referi a essa noção quando tratei das nulidades absolutas, no meu livro sobre Execução, como o conjunto de requisitos dos atos processuais, impostos de modo imperativo para assegurar a proteção de interesse público precisamente determinado, o respeito a direitos fundamentais e a observância de princípios do devido processo legal, quando indisponíveis pelas partes.

Entre esses princípios indisponíveis, porque impostos de modo absoluto, apontei então: a independência, a imparcialidade e a competência absoluta do juiz; a capacidade das partes; a liberdade de acesso à tutela jurisdicional em igualdade de condições por todos os cidadãos (igualdade de oportunidades e de meios de defesa); um procedimento previsível, eqüitativo, contraditório e público; a concorrência das condições da ação; a delimitação do objeto litigioso; o respeito ao princípio da iniciativa das partes e ao princípio da congruência; a conservação do conteúdo dos atos processuais; a possibilidade de ampla e oportuna utilização de todos os meios de defesa, inclusive a defesa técnica e a autodefesa; a intervenção do Ministério Público nas causas que versam sobre direitos indisponíveis, as de curador especial ou de curador à lide; o controle da legalidade e causalidade das decisões judiciais através da fundamentação ${ }^{10}$. A esses acrescento agora a celeridade do processo, pois a litigiosidade é uma situação de crise na eficácia dos direitos dos cidadãos que o juiz tem o dever de remediar com a maior rapidez possível (CPC, art. 125), especialmente após a introdução do novo inciso LXXVIII do artigo $5^{\circ}$ da Constituição pela Emenda Constitucional $n^{\circ}$ 45/2004. Acrescentaria também a garantia de uma cognição adequada pelo juiz, pois, esse é um dos objetivos essenciais de toda a atividade processual.

\footnotetext{
${ }^{8}$ V. Leonardo Greco, "Garantias fundamentais do processo: o processo justo", in Estudos de direito processual, ed. Faculdade de Direito de Campos, Campos dos Goytacazes, 2005, p. 255/257.

${ }^{9}$ Teresa Arruda Alvim Wambier (Nulidades do processo e da sentença, $6^{\mathbf{a}}$ ed., Revista dos Tribunais, São Paulo, 2007, p.164) alerta com razão que nem tudo o que o juiz aprecia de ofício encontra fundamento na ordem pública. Entretanto, aqui pretendo fixar que a ordem pública é um limite à livre disposição das partes, sem prejuízo de o juiz poder examinar outras questões, como a conexão, que não são regidas por normas imperativas ou princípios indisponíveis.

${ }^{10}$ Leonardo Greco, O Processo de Execução, vol. 2, ed. Renovar, Rio de Janeiro, 2001, p. 265/266.
} 
3. Momento de eficácia. CARNELUTTI esclarece que a eficácia jurídica processual de um ato ou fato ocorre quando ele determina a mundaça de uma situação jurídica processual $^{11}$. Até o advento do Código de Processo Civil de 1973, a eficácia dos atos dispositivos das partes ficava sempre condicionada à homologação ou ao deferimento judicial. PONTES DE MIRANDA exalta essa diferença de tratamento, afirmando ter sido profunda a alteração determinada nessa matéria pelo artigo 158 do Código de 1973, em relação ao antigo artigo 16 do Código de 1939. No novo regime, todos os atos processuais, consistentes em declarações de vontade, inclusive as omissões, quando delas resulte criação, modificação ou extinção de alguma situação jurídica, produzem imediatamente esses efeitos. Excetua-se apenas a desistência da ação, que deverá ser objeto de sentença terminativa ${ }^{12}$.

A eficácia dos atos de disposição das partes não poderia ficar subordinada a condições ou a termos, na medida em que a seqüência dos atos do processo não deve sofrer quebra de continuidade. Nas palavras de BARBOSA MOREIRA, poderiam ser postos em risco a certeza e a segurança no desenvolvimento do processo ${ }^{16}$. Penso, entretanto, ser impossível generalizar essa regra. É certo que o processo deve seguir um procedimento prédeterminado, que siga as prescrições da lei. Mas nada impede que as partes ajustem a dispensa da prova testemunhal, caso a perícia já deferida esclareça determinado fato. $\mathrm{O}$ processo terá seguimento com ou sem a produção da prova testemunhal, conforme o resultado da perícia.

Com freqüência, se ajusta a suspensão do processo de execução, pelo tempo necessário ao pagamento do crédito em prestações periódicas, retomando-se o seu curso se inadimplida alguma das prestações (CPC, art. 792).

A convenção das partes pode, por seu lado, fixar termo para a eficácia de ato de disposição, como a suspensão do processo (CPC, art. 265, inciso II, e $\S 3^{\circ}$ ).

4. Revogabilidade. O tratamento da revogabilidade dos atos de disposição das partes, nos sistemas em que a eficácia desses atos depende de homologação judicial, é normalmente associado à superveniência ou não dessa homologação ${ }^{13}$. Para CARNELUTTI, todas as declarações de vontade ou de ciência seriam revogáveis, embora

\footnotetext{
${ }^{11}$ Ob.cit., p.69.

${ }^{12}$ Pontes de Miranda, Comentários ao Código de Processo Civil, tomo III, $3^{\mathrm{a}}$ ed., com atualização legislativa de Sergio Bermudes, Forense, Rio, 1996, p. 61/62. ${ }^{16}$ Ob. cit., p.95.

${ }^{13}$ Barbosa Moreira, ob. cit., p. 90.
} 


\section{Quaestio Iuris}

vol.04, n-01. ISSN 1516-0351

não necessariamente quanto a todos os seus efeitos ${ }^{14}$. Todavia, atualmente entre nós, é preciso considerar o alcance do disposto no já citado art. 158 do Código de Processo Civil, segundo o qual, salvo na desistência da ação, os atos das partes, unilaterais ou bilaterais, seja qual for o seu conteúdo, produzem efeito imediato, independentemente de sua homologação ou aprovação pelo juiz. Essa eficácia imediata, não condicionada à homologação judicial, impõe limites mais rígidos à sua revogação. Parece-me que esses limites devem ser encontrados não mais na homologação judicial, mas em pelo menos uma destas três circunstâncias: a) a necessidade de permanente continuidade do processo em direção ao seu fim, que não deve ser condescendente com retrocessos, a não ser por um motivo justificável, alegado de boa fé; b) o direito adquirido, decorrente da prática ou omissão do ato por uma parte em benefício da outra, que gere direito subjetivo em favor da outra; ou c) como conseqüência de uma dessas duas circunstâncias, a preclusão temporal ou consumativa, que impede que o ato praticado ou omitido tenha uma nova oportunidade de ser manifestado.

Nos atos de disposição extrajudicial, a revogabilidade dependerá normalmente da vontade das próprias partes (conjuntamente, em caso de ato convencional) ou de expressa previsão legal. Trazidos para o processo, produzirão efeitos desde logo, podendo do mesmo modo ser revogados para o futuro, desde que não incorram em qualquer das três hipóteses mencionadas no parágrafo anterior, ou se a lei expressamente a admitir, como ocorre na hipótese da revogação da procuração (CPC, art. 44).

5. Regime legal. Como qualquer ato jurídico, o ato processual exige sujeito capaz, objeto lícito e forma prescrita ou não defesa em lei (Código Civil, art. 104). Mas qual é o sistema normativo que rege a capacidade do sujeito, a licitude do objeto e a forma do ato de disposição processual?

A meu ver, todo ato do processo, ou seja, todo ato que seja praticado na relação processual, como seu elemento integrante, deve observar a capacidade do sujeito, o conteúdo e a forma prescritos pela própria lei processual. O direito processual tem as suas próprias regras. Ainda que esses atos produzam efeitos de direito material, sua subordinação ao regime processual é inerente à sua natureza processual.

\footnotetext{
${ }^{14}$ Francisco Carnelutti, Sistema de derecho procesal civil, v. III, ed. Uteha Argentina, Buenos Aires, 1944, p.115.
} 


\section{Quaestio Iuris}

vol.04, n0.01. ISSN 1516-0351

Entretanto, cabe considerar que há atos do processo que possuem conteúdo de direito material, como uma transação. Se celebrada através de ato processual, deve observar em todos os seus elementos o direito processual, mas também deverá observar, quanto ao conteúdo ou objeto, o direito material de regência da respectiva relação jurídica. Todavia, se um ato processual contém um negócio de direito material em que este exige capacidade ou forma diversos dos prescritos pela lei processual, não se pense que o ato processual nesses aspectos deva observar o direito material. Seu conteúdo deverá respeitá-lo, mas a capacidade dos sujeitos e a forma se desprendem do direito material para submeter-se às regras próprias do direito processual. Assim, por exemplo, antes do novo Código Civil, que reduziu a maioridade dos 21 para os 18 anos, o indivíduo nesse faixa etária somente podia celebrar uma transação assistido pelo seu representante legal. Entretanto, no juizado especial, ele podia fazê-lo sem essa assistência, porque autorizado pela lei processual (Lei 9.099/95, art. $8^{\circ}, \S 2^{\circ}$ ). Se a alienação de um imóvel, pela lei civil, exigiria escritura pública, podia ela ser ajustada no processo através de simples petição, sem a solenidade da escritura pública.

Mas também existem atos das partes que são praticados fora do processo, embora destinados exclusivamente a nele produzir efeitos. No momento da sua prática eles não integram a relação processual, embora devam vir a ser nela posteriormente documentados e aí produzir efeitos. É o caso da procuração outorgada ao advogado. Apesar de serem atos extraprocessuais, deverão observar a capacidade, o conteúdo e a forma prescritos pelo direito processual. Diferentemente, se forem atos extraprocessuais destinados a produzir efeitos de direito material e de direito processual. Estes últimos, quanto à capacidade e à forma, deverão observar o respectivo direito material, mas quanto ao conteúdo reger-se-ão tanto pelo direito material quanto pelo direito processual, podendo ocorrer que sejam considerados lícitos e eficazes para um e não para outro.

A prevalência do direito material ou do direito processual, quanto à capacidade e à forma, se os atos forem praticados fora ou dentro do processo ou neste exclusivamente destinados a produzir efeitos, e a observância, quanto ao conteúdo, de um e de outro, na medida em que os efeitos dos atos devam produzir-se neste ou noutro plano, são princípios que somente expressa disposição legal em contrário pode derrogar, porque, embora, no Brasil, a União possa legislar sobre o direito processual e também sobre grande parte do direito material, o direito processual tem os seus próprios princípios, como o princípio pro 


\section{Quaestio Iuris}

vol.04, n-01. ISSN 1516-0351

actione e o da liberdade das formas, que facilitam o acesso à justiça mesmo de sujeitos ou entes que não têm personalidade jurídica ou capacidade civil e relegam a plano secundário muitas garantias formais supridas pela instrumentalidade do processo e pela sua permanente sujeição à supervisão da mais qualificada e confiável autoridade pública, que é o juiz, que não deve ser entendida como supressora da liberdade das partes, mas fiscalizadora da adequação do seu exercício com os fins institucionais do processo.

6. Análise de alguns atos em espécie. Fixados esses critérios básicos, passarei a examinar algumas espécies de atos de disposição das partes, judiciais e extrajudiciais, especialmente quanto aos limites do poder de disposição, ao momento de sua eficácia, ao seu regime jurídico processual ou extraprocessual e à possibilidade de sua revogação.

6.1. Pactum de non petendo. Uma primeira espécie convencional extrajudicial é o chamado pactum de non petendo. Nas suas origens romanas correspondia ao compromisso pelo qual o credor se obrigava, em certas circunstâncias, como a do compromisso arbitral, a não exigir judicialmente o pagamento do seu crédito ${ }^{15}$.

O instituto, que é também citado como correspondente ao perdão da dívida ${ }^{16}$, pode ser equiparado à renúncia à tutela jurisdicional, a que fiz alusão no meu estudo sobre as garantias fundamentais do processo, no qual manifestei opinião no sentido da sua plena admissibilidade, desde que as circunstâncias de que se cerque evidenciem que ela foi livre e consciente, não imposta pela necessidade de livrar-se de qualquer espécie de sujeição, nem como condição de acesso a quaisquer bens ou direitos ${ }^{21}$.

O direito moderno apresenta outras modalidades de renúncia à jurisdição, como a submissão à justiça interna das associações de opinião e a pactuação das chamadas obrigações de paz nas relações trabalhistas e em certas comunidades empresariais.

Associações de opinião são entidades que congregam pessoas partidárias de certas correntes políticas, integrantes de determinados grupos étnicos ou religiosos, simpatizantes ou praticantes de determinado esporte ou hobby que, em benefício da fidelidade e da coesão de todos os participantes em torno das regras comuns de convivência, renunciam a disputar na justiça estatal eventuais divergências surgidas no

\footnotetext{
${ }^{15}$ Vittorio Scialoja, Procedimiento civil romano, ed. EJEA, Buenos Aires, 1954, p.434.

${ }^{16}$ Humberto Cuenca, Proceso civil romano, ed. EJEA, Buenos Aires, 1957, ns.287, 290, 292 e 300.

${ }^{21}$ Leonardo Greco, “Garantias ...”, p.248.
} 


\section{Quaestio Iuris}

vol.04, n-01. ISSN 1516-0351

seio da respectiva associação. TROCKER, na sua principal obra, mostrou como a sociedade européia respeita essa autonomia das associações privadas, desde que elas sejam capazes de estruturar internamente órgãos de solução de conflitos entre os associados, dotados da necessária independência em relação às suas esferas dirigentes, e desde que no processo interno de apuração e imposição de sanções aos associados sejam assegurados o contraditório, a ampla defesa e a motivação das decisões ${ }^{17}$. No Brasil, temos uma limitada experiência desse tipo, não propriamente de renúncia à jurisdição, mas de postergação da sua invocação, nas associações desportivas, por força do disposto no art. 217 da Constituição Federal.

As obrigações de paz são pactuações comuns nas relações trabalhistas entre patrões e empregados e nas relações empresariais, especialmente em alguns países desenvolvidos, nas quais os interessados se comprometem a não ingressar em juízo e não deflagrar ações de hostilidade em relação ao adversário, sem antes submeter o litígio a um foro de negociação geralmente composto por representantes qualificados das duas classes, no caso das relações trabalhistas, ou à assembléia da associação empresarial a que os dois litigantes sejam filiados, no caso de relações empresariais, em busca de uma solução que atenda aos interesses de ambos e da própria comunidade ${ }^{18}$. Tímida obrigação de paz é a obrigação de submeter o conflito coletivo de trabalho à negociação coletiva, como condição necessária para o ajuizamento do dissídio coletivo, conforme previsão dos $\S \S 1^{\circ}$ e $2^{\circ}$ do art. 114 da Constituição, o último com a redação da Emenda Constitucional ${ }^{\circ}$ $45 / 2004$.

Essas convenções me parecem plenamente válidas, desde que revestidas das exigências mínimas de renúncia à jurisdição acima expostas, a saber, pactuadas de forma absolutamente livre e consciente, e não como meios de obter algum benefício imediato ou de livrar-se de algum mal iminente.

$\mathrm{Na}$ verdade, as obrigações de paz não são propriamente pactos de renúncia à tutela jurisdicional, mas de postergação do ingresso em juízo enquanto se desenrolam as negociações dentro dos órgãos representativos da comunidade. Essa postergação deve ter um limite temporal razoável e não pode impedir o imediato ingresso em juízo sempre que

\footnotetext{
${ }^{17}$ Nicolò Trocker, Processo civile e Costituzione, ed. Giuffrè, Milano, 1974, p. 248.

${ }^{18}$ V. Gabriel Aubert, L'obligation de paix du travail - étude de droit suisse et comparé, ed. Georg - Librairie de l’Université, Genève, 1981, passim.
}

Revista Quaestio luris, vol.04, no01. ISSN 1516-0351 p.720-746 731 


\section{Quaestio Iuris}

qualquer das partes necessitar de alguma modalidade de tutela de urgência. Também nos procedimentos sancionadores internos das associações de opinião deve existir esse limite temporal e a ressalva da possibilidade imediata de tutela judicial de urgência.

Em um como em outro caso (associações de opinião ou obrigações de paz) não estamos diante de uma convenção de arbitragem, mas de ausência temporária da possibilidade de ingresso em juízo.

Torna-se relevante no estudo do tema definir se essas pactuações têm conteúdo de direito material ou processual ${ }^{19}$, isto é, se o conteúdo do direito material somente se perfaz, tornando-se exigível em juízo, após o cumprimento da consulta prévia ou da condição temporal, nas obrigações de paz, ou desta e do procedimento sancionador associativo, nas associações de opinião; ou se se trata apenas de falta de condição da ação, o interesse de agir, e, portanto, do direito à jurisdição que está sujeito à implementação dessas circunstâncias. BARBOSA MOREIRA assinala ${ }^{25}$ que a doutrina tem admitido convenções processuais condicionais, embora possam elas perturbar a marcha do processo. Parece-me que se essas convenções antecedem ao processo não ocorre esse risco. Em minha opinião, não é o direito material que deixou de preencher um dos seus requisitos ou está com a sua eficácia subordinada a uma condição. O direito material pode ser plenamente eficaz antes mesmo do preenchimento das circunstâncias apontadas, mas apenas a sua postulação judicial foi diferida. Nesses casos, o não implemento desses requisitos suprime o interesse de agir, ressalvada a necessidade de tutela de urgência.

Diferente será a solução, naquelas hipóteses em que o direito é declarado desde logo inexigível judicialmente. Aqui, mais do que a simples ausência de condição da ação, parece-me configurado verdadeiro pacto de non petendo, correspondente à declaração da inexistência do direito material ou ao perdão da dívida. Foi o que aconteceu com o acordo relativo aos expurgos das contas do FGTS, objeto da Lei Complementar n 110/2001, em que o trabalhador, que aderiu ao acordo, além de concordar com os termos, percentuais e prazos ajustados com a Caixa Econômica Federal, assinou declaração "de que não está nem ingressará em juízo discutindo os complementos de atualização monetária" expurgados.

\footnotetext{
${ }^{19}$ V. analogamente Trocker, ob. cit., p.270, sobre postergações semelhantes determinadas pela própria lei.

${ }^{25}$ Ob. cit., p.95.
} 


\section{Quaestio Iuris}

Verdadeira renúncia ao direito material e não apenas ao direito de ingressar em juízo, que não satisfaz aos requisitos acima, quais sejam, a livre e consciente pactuação, posto que induzida como meio de obter benefício imediato, além do desrespeito ao equilíbrio contratual e à paridade de armas, diante da evidência da manifesta posição de vantagem da Caixa Econômica Federal na celebração do acordo e em qualquer eventual disputa do direito material em juízo. Se, apesar da renúncia, o direito for pleiteado em juízo e o julgador considerar válida a pactuação, julgará improcedente o pedido. Se, ao contrário, reputar nula a renúncia, julgará provavelmente procedente o pedido, salvo se subsistir algum outro fundamento para rejeitá-lo.

Quanto ao momento da eficácia, cumpre analisar as diversas hipóteses mencionadas. Nas associações de opinião, a eficácia da postergação ocorrerá no momento em que, configurado o litígio, mas ainda não concluído o procedimento sancionador interno e não atingido o seu limite temporal, carece o prejudicado de interesse de agir judicialmente, exceto para a propositura de medidas de urgência. Nas obrigações de paz, a eficácia darse-á também no momento em que, configurado o litígio, mas ainda não concluídas as negociações entre as entidades de classe ou dentro do órgão de representação da comunidade e não atingido o seu limite temporal, igualmente subsistirá a falta de interesse de agir. Já na renúncia ao direito ou na quitação extrajudicial de dívida, o pacto é eficaz desde a sua celebração, salvo disposição legal ou contratual em contrário.

A revogabilidade dependerá da vontade conjunta das partes (Código Civil, art.472) ou da previsão legal. No momento em que ocorrer essa revogação, configurar-se-á desde logo o interesse de agir para o exercício da ação judicial ou para a sua continuidade, se já proposta, nas hipóteses de associações de opinião e de obrigações de paz, enquanto na revogação da renúncia ao direito ou da quitação, restabelece-se o direito material com toda a sua eficácia. Se nesse momento estiver pendente ação judicial, a revogação constituirá direito superveniente, nos termos do art. 303, inciso I, do Código de Processo Civil.

E o regime legal é o preconizado acima, salvo disposição legal expressa em contrário. Ou seja, a capacidade e a forma reger-se-ão pelo direito material, enquanto o conteúdo obedecerá às regras do direito material e, quanto aos seus efeitos processuais (carência de ação, julgamento de mérito etc.), ao direito processual. 


\section{Quaestio Iuris}

vol.04, n0.01. ISSN 1516-0351

6.2. Pactum de foro prorogando. O artigo 111 do Código de Processo Civil prevê o acordo de eleição de foro, desde que conste de contrato escrito e se refira expressamente a determinado negócio $\left(\S 1^{\circ}\right)$.

$\mathrm{Na}$ esteira de jurisprudência constante posterior ao Código de Defesa do Consumidor, a Lei 11.280/2006 facultou ao juiz declarar de ofício a nulidade da cláusula de eleição de foro em contrato de adesão (art. 112, parágrafo único, do CPC), determinando a prorrogação da competência do juiz perante o qual a causa tenha sido proposta, caso não tenha ele declinado da sua competência na forma do dispositivo anteriormente mencionado ou se não oferecida pelo réu exceção de incompetência (art. 114).

Essas novas regras não são de fácil integração com as anteriormente vigentes em matéria de incompetência relativa, porque, em verdade, criaram hipótese de declaração de ofício de uma nulidade relativa, que se convalida se não for argüida, nem declarada.

Ocorre que a lei não estabelece em que momento o juiz pode declarar a nulidade da cláusula de eleição de foro, nem em que momento se considerará prorrogada a sua competência por não ter sido a incompetência argüida ou declarada.

Parece-me que a nulidade ou a excessiva onerosidade da cláusula de eleição de foro constituem matéria que pode exigir dilação probatória, ainda que sumária. Assim, se a parte não argüiu a nulidade do foro de eleição através de exceção de incompetência e o juiz não declinou dessa competência até o despacho saneador, pois é até esse momento que ele deve examinar as questões processuais pendentes (art. 331, § $2^{\circ}$ ), ficará prorrogada a competência do juízo perante o qual foi a ação inicialmente proposta ${ }^{20}$.

Assim, ao foro de eleição se aplicam os limites já indicados anteriormente no presente estudo, sendo as regras da recente Lei 11.280/2006 uma exemplificação do segundo limite, relativo à exigência de respeito ao equilíbrio contratual e à paridade de armas. As regras de competência da parte final do artigo 95 do CPC e da Lei de Falências (Lei 11.101/2005, arts. $3^{\circ}$ e 76) são limitações à admissibilidade do foro de eleição em razão da ordem pública processual.

\footnotetext{
${ }^{20}$ Para Teresa Arruda Alvim Wambier, Luiz Rodrigues Wambier e José Miguel Garcia Medina, se o réu contestou a ação sem argüir a incompetência, não existirá motivo para a apreciação de ofício da nulidade da cláusula de eleição de foro, porque esta não terá prejudicado o exercício da defesa. Assim, a aplicação do novo parágrafo único do art. 112 deverá ser excepcional, reservada apenas para os casos de flagrante e evidente nulidade (in Teresa de Arruda Alvim Wambier, ob. cit., p.221).
} 
O momento de eficácia do pacto será o da propositura de qualquer ação decorrente do contrato celebrado entre as partes, que fixará e perpetuará a competência, nos termos do artigo 87 do Código de Processo Civil. A sua revogabilidade dependerá de novo acordo de vontade entre os contratantes que venham a ser partes no litígio ajuizado, não podendo depender da concorrência da vontade de outros contratantes que, eventualmente, não participem do litígio ajuizado, mas terá como limite temporal o ajuizamento da demanda porque, desde esse momento, a perpetuatio jurisdictionis não mais a permitirá. A única hipótese de eficácia temporal incidente ao processo já ajuizado é bem lembrada por PONTES DE MIRANDA, a que denomina de acordo sucessivo se, proposta a ação em determinado foro e oferecida pelo réu exceção de incompetência, vêm as partes, antes do julgamento desta, a pactuar manutenção da causa no juízo perante o qual foi proposta, desistindo o réu da referida exceção e, assim, prorrogando-se a competência do juízo original $^{21}$.

E, quanto ao regime legal, este é um caso de ato de disposição praticado fora do processo, mas destinado a produzir efeitos exclusivamente no processo judicial. Apesar de inserido em um contrato de direito material, a cláusula de foro de eleição será regida, tanto em relação à capacidade das partes, quanto ao conteúdo e a forma pela lei processual ${ }^{22}$. No artigo 111 do CPC encontram-se as regras especiais sobre o conteúdo e a forma que deverão ser observadas ${ }^{23}$. A validade da cláusula, de acordo com o seu regime processual, é absolutamente independente da validade do contrato como um todo, à luz do direito material que o rege.

6.3. Convenção de arbitragem. De acordo com o art. $1^{\circ}$ da Lei 9.307/96, a convenção de arbitragem é o contrato ou a cláusula de um contrato através dos quais pessoas capazes instituem ou se comprometem a instituir um juízo arbitral extrajudicial para resolver litígio relativo a direitos patrimoniais disponíveis.

\footnotetext{
${ }^{21}$ Pontes de Miranda, Comentários ao Código de Processo Civil, tomo II, $3^{\text {a }}$ ed., com atualização legislativa de Sergio Bermudes, Forense, Rio, 1995, p.322.

${ }^{22} \mathrm{Na}$ Alemanha há controvérsia sobre a natureza processual ou material dos acordos sobre competência, que são largamente utilizados e previstos nos $\S \S 38$ a 40 da ZPO. V. Stefan Leible, Proceso civil alemán, ed. Konrad Adenauer Stiftung, Medellín, Colômbia, 1999, p.124; Peter L. Murray e Rolf Stürner, German Civil Justice, Carolina Academic Press, Durham, North Carolina, 2004, p. 144.

${ }^{23}$ Pontes de Miranda (Comentários...tomo II, p.321) admite a validade de cláusula de eleição de foro em negócios jurídicos unilaterais, como as promessas de recompensa, bem como a sua vinculação não a determinado negócio jurídico, mas a um ato-fato ilícito, como o mau uso da propriedade, ou a um ato-fato jurídico, como uma descoberta científica.
} 


\section{Quaestio Iuris}

vol.04, n-01. ISSN 1516-0351

A cláusula compromissória de um contrato deve observar as disposições dos arts. $4^{\circ}$ a $8^{\circ}$ da referida Lei, enquanto o compromisso arbitral, que é um contrato típico, regerse-á pelos arts. $9^{\circ}$ a 12 do mesmo diploma e pelos arts. 851 a 853 do Código Civil. O compromisso não é necessariamente uma convenção extrajudicial, porque também pode adotar a forma judicial, ou seja, ser objeto de um ato interno de um processo judicial em andamento (Lei 9.307/96, art. $\left.9^{\circ}, \S 1^{\circ}\right)^{24}$.

Nem sempre a cláusula e o compromisso produzirão efeitos em um processo judicial, mas isso poderá ocorrer em diversas situações, como a instituição compulsória da arbitragem (Lei 9.307/96, art. $7^{\circ}$.), a ação de nulidade da sentença arbitral (art. 33) e a impugnação à execução da sentença arbitral (CPC, arts. 475-J a 475-N, introduzidos pela Lei 11.232/2005).

Nesses casos, poderá o juiz ser chamado a examinar os limites da autonomia da vontade das partes, à luz das regras de direito material acima referidas, podendo recusar a validade da arbitragem em razão da indisponibilidade do direito material (Lei 9.307/96, art. $1^{\circ}$ ), da violação do equilíbrio contratual e da paridade armas pela pactuação em contrato de adesão sem as cautelas legais $\left(\operatorname{art.} 4^{\circ}, \S 2^{\circ}\right.$ ) ou da ofensa aos princípios e garantias fundamentais da arbitragem e do processo arbitral (art. 32). Peculiaridade desse controle é que, diferentemente do que ocorre na maior parte dos atos de disposição processual das partes, esses limites somente podem ser examinados pela autoridade judiciária através de ações próprias, como a de instituição compulsória da arbitragem, a ação de nulidade do artigo 33 da Lei de Arbitragem ou a impugnação incidental à execução, ou ainda se argüida a existência de convenção ou sentença arbitral como matéria de defesa pela parte interessada (CPC, art. 301, inciso IX e $\S 4^{\circ}$ ), não me parecendo possível a sua apreciação ex-officio pelo juiz ${ }^{25}$.

A convenção arbitral produzirá efeitos desde o momento em que uma das partes no contrato decida manifestar à outra a intenção de instituir a arbitragem (Lei 9.307/96, arts. $5^{\circ}$ a $7^{\circ}$ ) ou desde que alegada a sua existência como matéria de defesa em processo judicial (CPC, últimos dispositivos citados).

\footnotetext{
${ }^{24}$ Uma modalidade de juízo arbitral instituído por convenção judicial está prevista nos arts. 24 a 26 da Lei dos Juizados Especiais (Lei 9.099/95).

${ }^{25}$ Teresa Arruda Alvim Wambier (ob.cit., p. 80/81), explorando a divergência de redação entre o inciso IX (convenção de arbitragem) e o $\S 4^{\circ}$ (compromisso arbitral), sustenta que, não tendo sido a cláusula compromissória mencionada no último dispositivo, deve ser reconhecida de ofício.
} 
Quanto à revogabilidade, enquanto objeto de um contrato privado, a convenção arbitral pode ser a qualquer tempo revogada pela mesma forma do contrato, com a anuência das mesmas partes. Os limites a essa revogabilidade encontram-se nos arts. $28 \mathrm{e}$ 29 da Lei 9.307/96. Antes da sentença arbitral, podem as partes livremente pôr fim ao litígio e à própria arbitragem. Proferida a sentença arbitral, estará exaurida a convenção e não será mais possível a sua revogação. A revogação tácita da convenção arbitral também ocorrerá no curso de processo judicial proposto sobre o mesmo litígio objeto da convenção ou do processo arbitral, se o réu não argüir a sua existência como preliminar da contestação (CPC, art. 301, inciso IX e $\S 4^{\circ}$ ). Não me parece possível essa revogação tácita depois de proferida a sentença arbitral.

Argüida a convenção arbitral como preliminar da contestação, mas ainda não extinto o processo sem resolução do mérito (CPC, art. 267, inciso VII), sendo essa questão livremente disponível pelo réu, pode este vir a dela desistir, consumando-se a sua revogação expressa, daí não resultando qualquer prejuízo para o autor, mas sempre antes da sentença arbitral.

O compromisso e a cláusula compromissória deverão obedecer ao regime contratual que lhes é próprio, quanto à capacidade das partes, ao conteúdo e à forma. Apenas a produção de seus efeitos e dos efeitos da sentença arbitral em processo judicial é que observará a lei processual. Se o compromisso tiver sido ajustado em processo judicial, entretanto, apesar do seu conteúdo contratual, deverá, como ato processual, revestir-se dos requisitos de validade impostos pela lei processual, quanto à capacidade dos sujeitos, à licitude do objeto e à forma, sem prejuízo de igualmente observar o regime jurídico do direito privado quanto ao conteúdo e ao objeto.

6.4. Autorização de juízos de equidade e de escolha da lei aplicável. Invocando o art. 127 do Código de Processo Civil, segundo o qual a decisão por eqüidade depende de expressa previsão legal, BARBOSA MOREIRA condena convenções processuais que autorizem o juiz a decidir por eqüidade ${ }^{26}$.

Parece-me que essa objeção do mestre não pode mais subsistir, a partir do advento da Lei de Arbitragem (Lei 9.307/96), que em seu artigo $2^{\circ}$ autorizou o convencionamento da arbitragem de eqüidade. Se o juiz cumpre a sentença arbitral adotada em juízo de eqüidade, deve ter a possibilidade de receber das partes, ele próprio, a confiança para a

\footnotetext{
${ }^{26}$ Ob. cit., p.94.
} 


\section{Quaestio Iuris}

vol.04, n-01. ISSN 1516-0351

formulação de juízos alheios a critérios de estrita legalidade. No Código italiano há previsão expressa dessa possibilidade no artigo 114, que permite o julgamento por eqüidade do mérito da causa que verse sobre direitos disponíveis, a pedido conjunto de ambas as partes.

Aliás, não é apenas o julgamento de eqüidade que pode ser livremente convencionado, desde que no âmbito dos direitos patrimoniais disponíveis. Também a escolha da lei de direito material aplicável a essas relações jurídicas, consoante previsão da mesma Lei de Arbitragem que se refere expressamente aos princípios gerais de direito, aos usos e costumes e às regras internacionais de comércio ${ }^{27}$.

Também tratados internacionais em vigor no Brasil se referem à possibilidade de submissão voluntária à lei de um determinado país, em matéria de obrigações, como ocorre com a Convenção de Nova Iorque de 10 de junho de 1958 (art. $5^{\circ}$ ). HAROLDO VALLADÃO, no seu anteprojeto de lei geral de aplicação de normas jurídicas, apontava apenas dois limites a essa estipulação: o abuso de direito e a ordem pública (art. 50) ${ }^{28}$. Também se aplicam a essas convenções, se por essas hipóteses não abrangidos, os limites já indicados anteriormente.

A eficácia da autorização para decisão por eqüidade, que fica restrita às questões de mérito, se produzirá a partir da instauração do processo judicial que verse sobre a correspondente relação jurídica. Já a da escolha da lei aplicável, como fonte de direito contratual, dar-se-á desde o momento de início da vigência do próprio contrato e, portanto, ainda antes de sua argüição em qualquer processo judicial. A revogação de uma e de outra poderá ocorrer convencionalmente a qualquer tempo, respeitadas até essa data e enquanto não modificadas por decisões judiciais posteriores, as adotadas até a revogação.

Salvo se celebradas através de ato praticado em processo em curso, como uma transação judicial, essas convenções estarão sujeitas, em todos os aspectos, ao direito material de regência do seu próprio conteúdo.

6.5. Proposições, convenções e omissões fáticas. Em que circunstâncias podem ser os fatos objeto de atos de disposição das partes é matéria complexa, que comportaria um estudo a parte. Cabe distinguir os fatos jurígenos dos fatos simples ou complementares. E

\footnotetext{
${ }^{27}$ É a chamada lex mercatoria (Carlos Alberto Carmona, Arbitragem e processo: um comentário à Lei 9.307/96, ed. Malheiros, São Paulo, 1998, p. 69/70).

${ }^{28}$ Jacob Dolinger e Carmen Tiburcio, Vade-mécum de Direito Internacional Privado, ed. Renovar, Rio de Janeiro, 1994, p.54.
}

Revista Quaestio luris, vol.04, no01. ISSN 1516-0351 p.720-746 738 


\section{Quaestio Iuris}

vol.04, n0.01. ISSN 1516-0351

entre os primeiros, cabe distinguir os constitutivos do direito alegado pelo autor dos fatos extintivos, modificativos ou impeditivos desse direito, que sustentam o direito alegado pelo réu.

Os fatos constitutivos do direito do autor integram o objeto litigioso, compondo a causa de pedir. Podem gerar direitos absolutos, como os direitos da personalidade e os direitos reais de gozo, também chamados de direitos autodeterminados; ou servir de fundamento a direitos relativos, como os direitos de crédito e os direitos reais de garantia, também denominados de direitos heterodeterminados ${ }^{29}$. Os direitos autodeterminados podem ser gerados pelos fatos inicialmente propostos ou por quaisquer outros, desde que possuam as mesmas características jurídicas.

Os fatos fundantes de direitos relativos, cabe ao autor alegá-los na petição inicial e o juiz não tem qualquer ingerência nessa escolha. Desde o ajuizamento produzem efeitos no processo $\left(\mathrm{CPC}\right.$, arts. 87 e $\left.219, \S 1^{\circ}\right)$. Até a citação, pode o autor unilateralmente alterar as proposições fáticas iniciais, seja para retirar, seja para incluir algum fato. Depois da citação e até o saneamento do processo, eventuais alterações dependerão da concordância do réu. E depois do saneador está proibida qualquer alteração (CPC, art. 264).

Já nos direitos absolutos, embora tenha o autor o ônus de enunciar os fatos geradores do seu direito na petição inicial, se ele não circunscrever expressamente a sua postulação apenas a esses fatos, poderá o juiz a qualquer tempo tomar conhecimento de ofício de quaisquer outros fatos com as mesmas características e, com base neles, julgar o pedido (CPC, art. 462), como poderá o próprio autor, depois da citação e do saneador alegá-los. Os fatos produzirão efeitos no processo desde a sua alegação ou revelação. Até a citação poderá o autor unilateralmente retirá-los do objeto litigioso; após a citação, mas antes do saneador, somente o poderá com a concordância do réu; após o saneador estará vedada qualquer restrição.

Já os fatos alegados pelo réu como fundamento do seu direito material, que se opõe ao do autor, integrando a chamada causa excipiendi, igualmente produzem efeitos no processo desde o ajuizamento da contestação (CPC, art. 326). Em geral, o juiz não pode conhecêlos de ofício, excetuados os geradores de direito indisponível do réu ou de fundamentos de defesa de ordem pública (CPC, art. 303, inciso II), como hoje a prescrição (CPC, art. 219, $\S 5^{\circ}$, com a redação da Lei 11.280/2006). A revogação unilateral da alegação destes

\footnotetext{
${ }^{29}$ V. Leonardo Greco, A teoria da ação no processo civil, ed. Dialética, São Paulo, 2003, p.64.
} 


\section{Quaestio Iuris}

últimos por parte do réu não me parece possível. Já a dos demais, inexistindo os fundamentos da indisponibilidade e da ordem pública, pode ocorrer até a sentença de mérito, inclusive em grau de recurso.

Nos limites aqui expostos, poderão as partes dispor a respeito da revelação de fatos jurígenos, unilateralmente, através de convenções ou até mesmo da omissão na sua alegação tempestiva.

E quanto aos fatos simples, que são os fatos secundários que servem para provar a existência dos fatos jurígenos, podem sempre ser conhecidos de ofício pelo juiz por ocasião do julgamento dos fatos, que ocorre em geral na sentença (CPC, art. 131). Produzem efeitos no processo desde o momento em que revelados no processo através de algum ato das partes ou de qualquer outro sujeito processual, não estando ao alcance de qualquer das partes dispor a respeito da sua revelação ou da sua apreciação pelo juiz.

O regime legal dos atos de disposição a respeito dos fatos será sempre o processual, ainda que objeto de convenção extraprocessual.

6.6. Disposições probatórias . As convenções sobre a distribuição do ônus da prova estão expressamente admitidas pelo parágrafo único do art. 333 do Código de Processo Civil, salvo se recaírem sobre direito indisponível ou se a convenção tornar excessivamente difícil a uma parte o exercício do direito. Respeitados esses limites, que favorecem a imputação desse ônus ao litigante que tiver mais facilidade de produção da prova do fato, as partes podem ajustar qual delas será prejudicada no julgamento, caso determinado fato relevante não fique comprovado ${ }^{30}$. Se extraprocessuais, tais convenções produzirão efeitos no processo a partir da sua argüição por uma das partes através de algum ato processual. Se reveladas ou praticadas depois do saneador, poderão obrigar o juiz a rever a sua deliberação a respeito das provas a serem produzidas.

Sua revogação somente pode ocorrer consensualmente, até a prolação da sentença, porque é nesse momento culminante que o juiz aplicará as consequiências definitivas das regras de distribuição do ônus da prova. A meu ver ocorrerá a revogação tácita se nenhuma das partes a invocar no momento da proposição das provas que se dá, normalmente, na petição inicial e na contestação (arts.282, inciso VI, e 300).

\footnotetext{
${ }^{30}$ V. o meu estudo "A prova no Processo Civil: do Código de 1.973 ao novo Código Civil", in Estudos de direito processual, ed. Faculdade de Direito de Campos, Campos dos Goytacazes, 2005, p.357/392.
} 
O regime dessas convenções será sempre o da lei processual.

Mas além dos limites bem definidos no parágrafo único do art. 333, que, segundo MOACYR AMARAL SANTOS ${ }^{31}$, se modelou no artigo 2.698 do Código Civil italiano, é preciso reconhecer a reduzida importância que atualmente possuem as regras relativas ao ônus probatório, que, de nenhum modo podem prejudicar o livre convencimento do juiz, servindo principalmente para auxiliá-lo em caso de dúvida.

Outras convenções probatórias também são admissíveis, desde que disponível o direito material que por elas possa ser atingido e que não seja tolhido o livre convencimento de juiz, nem limitado o seu poder de determinar de ofício a produção das provas que julgar necessárias à devida e veraz elucidação dos fatos. LOPES DA COSTA, apontado como um adversário das convenções de distribuição do ônus da prova, lecionava, entretanto: “ $\mathrm{O}$ que elas podem é dispensar de prova certos fatos, confessandoos fictamente, como não os contestando (art. 209) ou expressamente. Também se lhes permite combinarem, para determinados atos, certa prova".

Nada impede que essas espécies de convenções sejam celebradas no curso do processo já em andamento.

Exemplos outros, ainda poderiam figurar-se de convenções probatórias. BARBOSA MOREIRA $^{38}$ admite a convenção em que ambas as partes dispensem a indicação de assistentes técnicos. Como essa indicação é uma faculdade de cada uma das partes, nada impede que, de comum acordo, ambas resolvam não exercê-la. A convenção produzirá efeito a partir da prática do ato processual em que for comunicada no processo e somente poderá ser revogada consensualmente até a decisão do juiz que determinar a produção da prova pericial. Posteriormente, parece-me que não deveria ser admitida essa revogação, por violar a preclusão.

Inócuas, por outro lado, e até mesmo nulas, seriam outras espécies de convenções probatórias, como, por exemplo, a designação de comum acordo do perito único ou a limitação da investigação probatória à produção apenas de provas orais. No sistema brasileiro, não podem as partes limitar os poderes do juiz na investigação da verdade. Ainda que deva exercê-los normalmente em caráter subsidiário, não pode deles abrir mão.

\footnotetext{
${ }^{31}$ Moacyr Amaral Santos, Comentários ao Código de Processo Civil, vol. IV, $2^{\mathrm{a}}$ ed., Forense, Rio de Janeiro, 1977, p.40. ${ }^{38}$ Ob. cit., p. 92.
} 


\section{Quaestio Iuris}

Este pode aceitar a indicação do perito feita de comum acordo pelas partes, mas a deliberação final será de sua responsabilidade, não daquelas. Pode ele igualmente convencer-se não ser necessária ou útil qualquer outra prova, exceto as de natureza oral, acolhendo a sugestão das partes.

Em outros sistemas, encontram-se regras consagradoras de algum tipo de limitação à iniciativa probatória do juiz. Assim, no direito alemão, cabe às partes a indicação das testemunhas, não podendo o juiz de ofício determinar a inquirição de qualquer pessoa ${ }^{39}$. São sistemas em que mais acentuada é a autonomia das partes, com a conseqüente redução dos poderes do juiz.

Entre os atos de disposição probatória encontra-se a confissão, que pode ser extrajudicial ou judicial, subdividindo-se esta em espontânea ou provocada. Seu limite é a disponibilidade do direito material. O momento em que se inicia a produção dos seus efeitos é o da prática do ato de confissão judicial ou da revelação no processo do ato de confissão extrajudicial. A sua revogação depende de ação própria (CPC, art. 352), motivada em erro, dolo ou coação. Como fato processual que será livremente apreciado pelo juiz, a confissão não comporta retratação ${ }^{40}$. O seu regime legal é o processual (CPC, arts. $342 / 354)^{41}$.

6.7. Disposições sobre o procedimento. Mais difícil é a definição dos limites à disposição a respeito do procedimento, sabendo-se que, entre nós, este é regulado estritamente pela lei. Às vezes é a própria lei que abre margem à disciplina procedimental convencionalmente ajustada pelas partes, como na suspensão do processo, na modificação de prazos legais dilatórios ou no adiamento da audiência (CPC, art. 265-II, art. 181 e art. 453-I). Mas no silêncio da lei, o procedimento legal deve ser respeitado, pois ele é a garantia do tratamento isonômico de todos os cidadãos e na sua ritualidade se encontram as escolhas do legislador que procuram compor in abstracto de modo equilibrado as variadas situações subjetivas que nele se defrontam. A par dessa desejável homogeneidade genérica, é igualmente indispensável uma certa flexibilidade, para assegurar in concreto a paridade de armas e a ampla defesa ${ }^{42}$, assim como para fazer valer a natureza instrumental dos atos processuais, hoje não mais refém de inúteis formalismos. 
40 Giovanni Verde, Profili del processo civile, vol.2, Jovene ed., Napoli, $2^{\mathrm{a}}$ ed., 2002, p.118.

Em alentado estudo no Direito português (A confissão no direito probatório, ed. Coimbra, 1991, p.269/329), José Lebre de Freitas sustenta a eficácia substantiva da confissão. 42

V. Leonardo Greco, "Garantias fundamentais do processo: o processo justo", in Estudos de direito processual, ed. Faculdade de Direito de Campos, Campos dos Goytacazes, 2005, p. 225/286.

Assim, a prática de atos processuais pelas partes, sem a rigorosa observância dos requisitos estabelecidos pela lei, é fato do cotidiano forense, que não prejudica a validade da maioria dos atos assim praticados, na medida em que a sua finalidade foi atingida ou em que os requisitos inobservados não eram essenciais. Embora a teoria dos defeitos dos atos processuais ainda não esteja definitivamente construída, sofrendo excessiva influência do direito material, já tive oportunidade em outras ocasiões de ensaiar uma certa sistematização, ditada particularmente pelo progressivo declínio das chamadas nulidades absolutas e pela necessidade de restringir o culto à forma apenas ao descumprimento de regras impostas pela proteção da eficácia de normas imperativas protetivas de direitos indisponíveis, como já referido acima ${ }^{32}$.

Excluídos os casos de nulidades absolutas, se o ato praticado por uma das partes deixou de observar algum requisito essencial imposto pela lei e a outra parte não alegou a sua nulidade na primeira oportunidade que teve para falar nos autos, nem demonstrou ter sofrido algum prejuízo, a nulidade do ato estará sanada e o ato produzirá validamente, desde o momento em que foi praticado, todos os seus efeitos, sem que o juiz possa ter nesse resultado qualquer ingerência. Se o vício do ato é uma mera irregularidade, ou seja, o descumprimento de um requisito meramente útil do ato, o juiz pode exigir que a parte o regularize, se for possível. Mas se o juiz não atentar para tão leve defeito até o final do processo, a prestação jurisdicional será plenamente válida e o vício estará totalmente sanado. Enfim, o juiz deve velar pelo núcleo duro de princípios e garantias que formam a ordem pública processual, aceitando que as partes disponham com liberdade sobre a marcha do processo, desde que respeitado esse mínimo irredutível ${ }^{33}$.

Convenções sobre o procedimento, dentro desses limites, devem ser acolhidas e respeitadas pelo juiz. Entretanto, o legislador brasileiro nem sempre é fiel a esses critérios,

\footnotetext{
${ }^{32}$ V. Leonardo Greco, O Processo de Execução, vol.2, p. 256/290. e também: “O valor da causa e as custas iniciais no mandado de segurança", in Estudos de direito processual, ed. Faculdade de Direito de Campos, Campos dos Goytacazes, 2005, p. 175/196.

${ }^{33}$ Em perspectiva diversa, qual seja a de reforço dos poderes do juiz, José Roberto dos Santos Bedaque igualmente sustenta a flexibilidade da técnica no controle da validade dos atos processuais (Efetividade do processo e técnica processual, ed. Malheiros, São Paulo, 2006, p.107/111).
} 


\section{Quaestio Iuris}

vol.04, n-01. ISSN 1516-0351

atendo-se muitas vezes a uma rigidez procedimental incompatível com o respeito às garantias fundamentais do processo e totalmente distanciada do respeito devido à ordem pública processual. Cito como exemplo, o disposto no art. 182 do Código de Processo Civil, que proíbe às partes, mesmo de comum acordo, reduzir ou prorrogar os prazos peremptórios. Ora, a redução do prazo recursal de sentenças de partilha em inventários é prática usual, vedada por esse dispositivo. E por que não poderiam as partes prorrogar esse ou qualquer outro prazo processual, desde que o fizessem moderadamente, sem que isso implicasse em excessivo retardamento do desfecho do processo e, portanto, em comprometimento da celeridade?

Não ultrapassados esses limites e não comprometida a adequada cognição da causa pelo juiz, parece-me perfeitamente aceitável a regulação convencional do procedimento. Assim, por exemplo, se, mesmo não sendo evidente a complexidade da causa, ambas as partes decidirem optar por memoriais escritos em lugar das alegações finais orais, o juiz deve deferi-los (CPC, art. 454, § $\left.3^{\circ}\right)$.

Quanto ao uso de idioma estrangeiro ${ }^{34}$, não deve ser admitida a sua adoção convencional, porque prejudicaria a cognição adequada do juiz ou, pelo menos, a presunção de que o juiz somente é conhecedor do idioma nacional, não havendo qualquer segurança de que conheça tão bem idioma estrangeiro a ponto de nele poder exercer a função jurisdicional. A crescente circulação de documentos em certos idiomas estrangeiros, como o espanhol e o inglês, a nacionalização de expressões e frases e o uso da internet desde a infância poderão suprimir no futuro a necessidade dessa proibição.

De acordo com o art. 158 do CPC, os atos de disposição sobre o procedimento produzirão efeitos desde o momento em que forem praticados ou revelados no processo, salvo se a lei expressamente dispuser de modo diverso, como ocorre com a desistência da ação, que somente se consumará com a homologação judicial (CPC, art. 158, parágrafo único).

Os limites à sua revogabilidade deverão ser analisados caso a caso, à luz das diretrizes aqui expostas, cabendo observar, quanto à desistência da ação que, enquanto não homologada, podem ela e a concordância do réu ser revogadas unilateralmente, pois sua eficácia depende dessa homologação, não havendo qualquer situação jurídica definitivamente consolidada antes dela.

\footnotetext{
${ }^{34}$ V. Barbosa Moreira, ob.cit., p. 91.
} 


\section{Quaestio Iuris}

Como atos de conteúdo exclusivamente processual, seu regime é, em todos os aspectos, o da lei processual.

7. Considerações finais. A partir do marco teórico aqui delineado, espero, em estudos subseqüentes, dar seqüência à investigação ora iniciada, analisando todas as situações jurídicas em que possam ocorrer os atos de disposição das partes, observando-os sob os quatro aspectos inicialmente propostos - limites, momento de eficácia, revogabilidade e regime legal - e, eventualmente mais algum outro que contribua para a sua compreensão e sistematização.

Estarão sob o foco desses estudos as seguintes situações, previstas no Código de Processo Civil: a) a possibilidade de substituição do réu na nomeação à autoria (arts. 65 e $66)$; b) a substituição do alienante ou cedente pelo adquirente ou cessionário (art. 42, § $1^{\circ}$ ); c) o reconhecimento do pedido (art. 269, inciso II); d) a transação judicial (arts. 269, inciso III; 475-N, incisos III e V, e 794, inciso II) a suspensão do processo por convenção das partes (arts. 265, inciso II, e 792); f) o adiamento da audiência por convenção das partes (art. 453, inciso I); g) o requerimento conjunto de preferência no julgamento perante os tribunais (art. 565, parágrafo único); h) as convenções sobre prazos (art. 181); i) as convenções sobre alegações finais orais de litisconsortes (art. 454, § $1^{\circ}$ ); j) a desistência da ação (arts. 267, $\S 4^{\circ}$, e 158, parágrafo único); 1) a conciliação em audiência (arts. 447/449); m) a desistência da execução (art. 569), n) a liquidação por arbitramento por convenção das partes (art. 475-C, inciso I); o) a administração de estabelecimento penhorado (art. 677, $\S 2^{\circ}$ ); p) a escolha do juízo da execução (art. 475-P, parágrafo único); q) a escolha da prestação nas obrigações alternativas (art. 571); r) a escolha do foro pela Fazenda na execução fiscal (art. 578, parágrafo único); s) a escolha do meio executório pelo exeqüente (art. 568); t) a escolha do bem na entrega de coisa incerta (art. 629); u) a opção do exequiente pelas perdas e danos na execução de obrigações de fazer (art. 633); v) a execução da obra pelo próprio exeqüente nas prestações de fazer (art. 637); x) o depósito em mãos do executado com a anuência do exeqüente (art. 666, § $1^{\circ}$ ); z) a desistência da penhora pelo exeqüente (art. 667, inciso III); aa) a sub-rogação ou alienação judicial do crédito penhorado (art. 673); bb) o acordo sobre a forma de administração na penhora de estabelecimento (art. 677, $\S 2^{\circ}$ ); cc) a dispensa da avaliação se o exeqüente aceitar a estimativa do executado (art. 684-I); dd) a opção do exeqüente pela adjudicação ou pela 


\section{Quaestio Iuris}

alienação particular (art. 686); ee) a substituição da arrematação pela alienação via internet a requerimento do exeqüente (art. 689-A); ff) a nomeação do administrador no usufruto (art. 719); gg) a escolha do rito da execução de alimentos (arts. 732/735); hh) a opção do executado pelo pagamento em prestações (art. 745-A); ii) o acordo de pagamento amigável pelo insolvente (art. 783); jj) a escolha de depositário de bens seqüestrados (art. 824-I); 11) o acordo de partilha amigável (art. 1.031); mm) a alienação de bens em depósito judicial (art. 1.113, § $3^{\circ}$ )

Além dessas hipóteses de atos de disposição, cogito examinar algumas outras, existentes em outros ordenamentos processuais, mencionadas pela doutrina ou possivelmente compatíveis com o ordenamento brasileiro, como a renúncia bilateral antecipada do recurso futuro, a penhora em lugar inacessível, a não impugnação do valor da causa, a escolha do procedimento, o acordo de alienação antecipada dos bens penhorados e a convenção sobre a escolha do bem a ser penhorado.

Talvez seja ainda muito cedo para conclusões definitivas, mas, de qualquer modo, parece estar aberta a porta para uma compreensão mais precisa sobre a relação de equilíbrio que deve existir entre os poderes do juiz e os poderes de disposição das partes no processo civil brasileiro. A cooperação e o diálogo humano, que devem constituir o clima dominante no desenvolvimento do processo, exige o mútuo reconhecimento das posições de vantagem que cada um dos interlocutores está em condições mais favoráveis de tutelar, sem rivalidades, nem autoritarismos, mas no espírito construtivo do processo mais justo possível e da conseqüente solução mais adequada possível da causa. 